BEATA MARIA NOWAK

Pedagogium - Wyższa Szkoła Nauk Społecznych

$w$ Warszawie

\title{
INTERDYSCYPLINARNE, SIECIOWO-SYSTEMOWE PODEJŚCIE DO PROCESU READAPTACJI I REINTEGRACJI SPOŁECZNEJ OSÓB SKAZANYCH I ICH RODZIN
}

\begin{abstract}
Nowak Beata Maria, Interdyscyplinarne, sieciowo-systemowe podejście do procesu readaptacji i reintegracji spotecznej osób skazanych i ich rodzin [Interdisciplinary, Network and Systemic Approach to the Social Readaptation and Reintegration Process of Convicts and Their Families]. Studia Edukacyjne nr 42, 2016, Poznań 2016, pp. 233-249. Adam Mickiewicz University Press. ISSN 1233-6688. DOI: $10.14746 /$ se.2016.42.14

The author presents a holistic, network and systemic approach to the provision of assistance and support for individuals who are marginalised, at risk of exclusion and excluded. The author sees the adaptation of the clustering idea and theory and the compatible coopetition strategy as a real chance for a breakthrough in thinking about social re-adaptation and reintegration and for an effective modernisation of an inefficient prevention and social rehabilitation system.
\end{abstract}

Key words: social readaptation, the idea of clustering, network and system approach

\section{Wprowadzenie}

Wiele przemawia za tym, że polski system profilaktyki i resocjalizacji oraz sprzężony z nim (przynajmniej teoretycznie) system pomocy postpenitencjarnej wykazują znamiona znacznej dysfunkcji ${ }^{1}$. Po pierwsze, efekty resocjalizacji są mierzone za pomocą wskaźników negatywnych, no bo czym innym jest szacowanie wskaźnika recydywy? Po drugie, skazani opuszczający instytucje resocjalizacyjne nie są ani monitorowani, ani profesjonalnie

1 Najwyższa Izba Kontroli, Readaptacja społeczna skazanych na wieloletnie kary pozbawienia wolności, Warszawa, listopad 2015. 
zaopatrywani $\mathrm{w}$ informacje podstawowe i niezbędne dla ich pozytywnej readaptacji do życia na wolności. Wracają zwykle do swoich patogennych środowisk. A tam są stygmatyzowani², podobnie jak ich rodziny, z którymi najczęściej nikt nie pracuje. Pomoc społeczna uskutecznia rozdawnictwo środków pieniężnych, pracownicy socjalni w większości przypadków nie wykorzystują kontraktu socjalnego, uznanego za najbardziej efektywny w procesie readaptacji społecznej3, a kuratorzy sądowi, przeciążeni czynnościami biurokratycznymi oraz liczbą dozorów i nadzorów, stają się niewydolni w wykonywaniu swoich obowiązków służbowych ${ }^{4}$. Tak można w największym skrócie scharakteryzować aktualne działania systemowe. Oczywiście są to jedynie ogólne tendencje, które dają obraz negatywny. Nie można jednak zapominać o działaniach podejmowanych przez społeczności lokalne i ludziach dobrej woli, którzy niosą efektywną pomoc wielu skazanym i skutecznie wspierają ich $\mathrm{w}$ trudnym procesie readaptacji, a także o różnorakich projektach finansowanych przez Unię Europejską. Projekty te mają jednak ograniczony czas trwania, zwykle niewielki zasięg oraz incydentalny charakter.

Na opisaną wyżej sytuację realnego wpływu nie ma rozprawianie o kryzysie, wskazywanie niedociągnięć, czy prowadzenie badań empirycznych, które są rozproszone, a w większości przypadków oparte na miałkich założeniach metodologicznych i nie dające podstaw do uogólniania uzyskanych wyników oraz stricte diagnostyczne, prowadzone na podstawie deklaratywnych sposobów pozyskiwania danych badawczych.

We współczesnych realiach społeczno-ekonomicznych konieczne jest projektowanie pomocy readaptacyjno-reintegracyjnej opartej na wynikach wielozakresowych badań ogólnopolskich oraz dorobku wielu dyscyplin naukowych. Skuteczna pomoc oraz wsparcie postpenitencjarne wymaga bowiem budowania koalicji przez instytucje i organizacje zajmujące się różnorodnymi aspektami funkcjonowania osobistego i społecznego osób skazanych oraz ich rodzin - zarówno na etapie ich pobytu w instytucji resocja-

2 E. Goffman, Piętno. Rozważania o zranionej tożsamości, Gdańsk 2007.

${ }^{3}$ M. Rymsza (red.), Czy podejście aktywizujące ma szansę? Pracownicy socjalni i praca socjalna w Polsce 20 lat po reformie systemu pomocy społecznej, Warszawa 2011; tegoż, Pracownicy socjalni i praca socjalna w Polsce. Między stużbą spoteczna a urzędem, Warszawa 2012.

${ }^{4}$ Najwyższa Izba Kontroli, Wdrożenie i eksploatacja systemu dozoru elektronicznego oraz realizacja zadań przez sadowych kuratorów zawodowych w procesie wykonywania kary pozbawienia wolności w tym systemie, Warszawa, lipiec 2014; W. Liszke, Przygotowanie skazanego do życia po zwolnieniu z zakładu karnego przez kuratora sądowego, Probacja, 2009; B.M. Nowak, Skuteczność oddziaływań resocjalizacyjnych w percepcji kuratorów sądowych, [w:] Tożsamość osobowa dewiantów a ich reintegracja społeczna, red. A. Kieszkowska, Kraków 2011. 
lizacyjnej, jak i na etapie zakończenia kary i włączania się w nurt życia społecznego.

Wnikliwa i krytyczna analiza funkcjonowania aktualnego systemu pomocy postpenitencjarnej skłania do postawienia tezy, że w wysiłkach ukierunkowanych na jego modernizację należy dążyć do opracowania takiego modelu organizacji działań społecznych, by uwzględniał on zarówno powiązania pionowe, wynikające $z$ układu systemowego, jak i powiązania poziome, tworzone $w$ ramach lokalnej sieci międzyinstytucjonalnego działania na rzecz osób zmarginalizowanych, zagrożonych wykluczeniem i wykluczonych społecznie. Jestem przekonana, że jedynie taki sposób myślenia o procesie (re)integracji społecznej daje szansę na osiągnięcie pełnego, oczekiwanego efektu finalnego. W wymiarze indywidualnym jest nim bowiem powrót skazanych do bezkolizyjnego, a co najistotniejsze - samodzielnego i godnego życia w społeczeństwie, natomiast $\mathrm{w}$ wymiarze społecznym - znaczące zmniejszenie społecznych i ekonomicznych kosztów wynikających $\mathrm{z}$ ponownego osadzenia oraz zwiększenie poczucia bezpieczeństwa obywateli.

Do podjęcia próby opracowania koncepcji dającej szansę na przełamanie dotychczasowej niesprawności systemowej zainspirowały mnie, a tym samym sprowokowały współczesne nurty w zakresie socjologii, pedagogiki resocjalizacyjnej, psychologii oraz co najbardziej istotne - teorii organizacji i zarządzania.

W niniejszym artykule przedstawiam jedynie zarys sieciowo-systemowej koncepcji (re)integracji społecznej. Pełna jej wersja zostanie opublikowana w odrębnym, monograficznym opracowaniu wraz z wynikami najnowszych badań przeprowadzonych na przełomie 2015 i 2016 roku, w ramach autorskiego projektu „Porażka readaptacyjna w ocenie recydywistów penitencjarnych".

\section{Baza teoretyczna sieciowo-systemowej koncepcji (re)integracji społecznej}

W konstruowaniu koncepcji i teorii odnoszących się do sytuacji społecznych najbardziej przydatna jest goffmanowska strategia interakcyjna. Goffman rozumie sytuację jako środowisko, w którym będący w interakcji aktorzy społeczni funkcjonują $\mathrm{w}$ bezpośrednim sąsiedztwie, a zasięg środowiska fizycznego wyznaczany jest przez percepcję jego elementów. Współobecność interakcyjną, czyli bezpośrednią styczność aktorów wyznaczają 
reguły, zasady, czy też konwencje sankcjonowane kulturowo ${ }^{5}$. Zdaniem Goffmana, każda sytuacja społeczna jest nie tylko wyzwaniem - jest przede wszystkim

wysiłkiem poznawczym, wydatkowaniem i inwestowaniem zasobów aktorów w imię jednoczesnego zestrojenia wymogów struktury, odciskających się przemożnie $\mathrm{w}$ sytuacyjnej konfiguracji, z przebiegiem nie tylko teraźniejszych, ale i przyszłych wydarzeń 6 .

Sytuacja ma przy tym swój czas trwania: od momentu rozpoznania środowiska, czyli uświadomienia sobie obecności innych osób i rozpoczęcia rejestracji oraz wzajemnego monitorowania zachodzących wydarzeń, do momentu opuszczenia środowiska przez innych aktorów społecznych, czyli zakończenia interakcji.

Generalnie rzecz ujmując, zasadniczą presupozycję wizji goffmanowskiej stanowi systemowe postrzeganie świata społecznego $\mathrm{w}$ serii strukturalnie determinowanych "odsłon”, będących podwaliną ładu interakcyjnego, czyli kreowania siatki jawnych i ukrytych reguł kierujących interakcjami.

Na gruncie dokonań Goffmana swoje koncepcje budowali inni interakcjoniści symboliczni, jak między innymi skrajni przedstawiciele socjologicznego strukturalizmu, a w zasadzie sytuacjonizmu: Peter Blau i Herbert Blumer.

Zdaniem Blaua ${ }^{7}$, ułożenie elementów w każdej sytuacji jest niemal całkowicie determinowane przez strukturę społeczną i jej właściwości, co oznacza, że sytuacja społeczna staje się jedynie opisem przypadkowych i krótkotrwałych relacji między właściwościami określonej substancji społecznej, na które składają się cechy historyczne, genetyczne, czy psychiczne. Blumer ${ }^{8}$ natomiast wskazywane przez Blaua właściwości otoczenia zastępuje linią działania wypracowaną przez aktorów sytuacji społecznej $\mathrm{w}$ toku podejmowanych interakcji i sprawnej komunikacji ukierunkowanej na udzielanie sobie odpowiednich wskazań.

Obie te skrajne teorie nie oddają jednak w pełni swoistości teorii goffmanowskiej. Świat społeczny w rozumieniu Goffmana nie jest bowiem "splotem determinacji, indeterminacji, pospolitej przygodności, racjonalnej kalku-

${ }^{5}$ E. Goffman, Człowiek w teatrze życia codziennego, Warszawa 2009.

6 A. Manterys, Sytuacje społeczne, Kraków 2008, s. 13.

${ }^{7}$ Szerzej na temat teorii Blaua, m.in. w: P.M. Blau, Structures of social positions and structures of social relations, [w:] Theory building in sociology: assessing theoretical cummulations, red. J.H. Turner, Newbury Park 1989, s. 43-59.

${ }^{8}$ H. Blumer, Interakcjonizm symboliczny: perspektywa i metoda, przekł. G. Woroniecka, red. nauk. A. Manterys, Kraków 2007. 
lacji..."9, ale siatką współzależności, której zmienność wyznaczana jest liczbą i czasem trwania wzajemnych oddziaływań (osób, przedmiotów, zjawisk). Jest miejscem, obszarem lub przestrzenią, w której ujawniane są i doświadczane fundamentalne i uniwersalne uwarunkowania życia społecznego, stanowiące swoiste tworzywo porządku interakcyjnego. To systemowe ujęcie świata społecznego stanowi istotę goffmanowskiej narracji.

Jednakże, stałość i trwanie społeczeństwa oparte jest na wkraczaniu w sytuacje rutynowe. Pojawia się zatem pytanie: Co się dzieje w sytuacjach problematycznych lub nowych? Otóż, analizy P. Halla, J.P. Hewitta i R. Stokesa ${ }^{10}$ wskazują, że sytuacje nowe lub problematyczne ewidentnie wymagają redefinicji znaczeń. Wynika to $\mathrm{z}$ faktu, że zawierają $\mathrm{w}$ sobie pewien element dezorganizacji, wstrząsający dotychczasowym ładem społecznym, który stanowi jednocześnie fundament, na którym można wyjaśniać problemy i konstruować nowy porządek. Chodzi bowiem o to, by przywrócić sprawną komunikację poprzez skonstruowanie koncepcji służącej zredefiniowaniu inkryminowanej sytuacji ${ }^{11}$.

Zdaniem Hewitta12, emergencja znaczeń (pojawianie się nowych jakości) sprowadza się do identyfikacji obecnych sytuacyjnie składników struktury społecznej oraz podejmowania kreatywnych działań, ukierunkowanych na umiejętne i sprawne wykorzystanie rutynowego tła społecznego. A zatem, nie rewolucja i burzenie zastanych elementów, ale ich modernizacja, czyli ulepszanie istniejącego systemu poprzez wprowadzanie nowych elementów oraz swoistą renowację tych, które nie funkcjonują prawidłowo.

Podejście Hewitta wzmacnia koncepcja Johna Loflanda, dookreślająca logikę analizy sytuacji społecznych. Lofland postrzega bowiem sytuację jako kontekst działania, określone miejsce dostępne aktorom społecznym w określonym czasie. Ważna dla niego jest skala sytuacji w czterech wymiarach: liczba ludzi zaangażowana $\mathrm{w}$ daną sytuację, obiekty fizyczne (wyposażenie), przestrzeń oraz czas. Dzięki ludzkiej skłonności do tworzenia wzorców wymiary te - pomimo możliwości zaistnienia nieskończonej liczby kombinacji - układają się w siedem zasymilowanych form, a są to: role, grupy, organizacje, światy, otoczenia i społeczeństwa. Takie ujmowanie sytuacji społecznych współgra z potrzebą działania lokalnego i znacząco uzasadnia sieciowo-systemowe ujmowanie procesu reintegracji społecznej.

${ }^{9}$ A. Manterys, Sytuacje społeczne, s. 21.

10 P.M. Hall, J.P. Hewitt, The quasi-theory of communication and the management of dissent, Social Problems, 1970, 18, 1, s. 17-27.

11 Właśnie ta teza stała się tezą wyjściową w moim dążeniu do zmodernizowania dotychczasowego układu systemowego.

$12 \mathrm{~J}$. Lofland, Doing social life: a qualitative study of human interaction In natural settings, New York 1976. 
Dla niniejszych rozważań istotne jest jednak podejście akcentujące negocjowany porządek interakcyjny, reprezentowane między innymi przez Beckera, Tuckera, Denzina, Wellmana i Straussa. Generalnie stanowisko to sprowadza się do stwierdzenia, że aktorzy społeczni będący podstawową siłą sprawczą są zdolni do autonomicznego działania w świecie ustrukturowanym, uporządkowanym społecznie i kulturowo. Świat ten i pojawiające się $\mathrm{w}$ nim sytuacje wymagają jednak podjęcia wysiłku ukierunkowanego na ich interpretację i dostosowanie się do określonych reguł, co jest możliwe dzięki zdolności i motywacji do tworzenia i przetwarzania znaczeń. Jednak, jak pisze Blumer, aktor społeczny „swoje zadanie konstruowania działania może wykonać byle jak, ale musi je wykonać"13. Podkreślona jest tu zatem aktywność podmiotu społecznego, który swoje miejsce negocjuje w splocie sytuacji pojawiających się w ustalonym porządku społecznym. Aktywność ta jest determinowana jego obecnością $\mathrm{w}$ sieci licznych interakcji wraz z innymi aktorami odgrywającymi swoje role $\mathrm{w}$ swoistych spektaklach na społecznej scenie. Co więcej, w toku transakcji dokonuje on ewaluacji siebie i własnych działań, a czyni to w perspektywie definicji sytuacji wypracowanych wspólnie $\mathrm{z}$ innymi podmiotami. W tym kontekście podejmuje role, wykonuje czynności społeczne, a w procesie komunikacji dokonuje samoregulacji.

Próbę połączenia współobecności kontekstów strukturalnego i negocjacyjnego, które określają logikę sytuacji społecznych podjął A.L. Strauss. Zdaniem tego Autora, dostępne sytuacyjnie są niemal wszystkie składniki strukturalne, które potencjalnie mogą być przedmiotem negocjacji. Interakcje traktuje Strauss de facto jako transakcje przebiegające w licznych, różnorodnych i złożonych kontekstach. Takie ujmowanie kontekstu strukturalnego i negocjacyjnego prowadzi do finalnej tezy, że struktura jest swoistą areną dla procesu negocjacji. Thompson i Fine ${ }^{14}$ idą dalej i stwierdzają, że konsekwencje owych negocjacji przyczyniają się do wypracowania roboczego konsensusu, polegającego na rekonstrukcji dotychczasowego przebiegu działań.

Interakcjoniści stoją przy tym na stanowisku, że w rzeczywistości mamy do czynienia nie tylko z potencjałem dostępnym aktorom społecznym, na który składają się wszystkie składniki danej sytuacji, ale też z pewnym granicznym jej wycinkiem, który nie podlega negocjacji czy interpretacji. Co istotne, mechanizm akomodacji, który jest udziałem każdego podmiotu spo-

${ }^{13}$ H. Blumer, Interakcjonizm symboliczny, s. 15.

${ }^{14}$ L. Thompson, G.A. Fine, Socially shared cognition, affect and behavior: a review and integration, Personality and Social Psychology Review, 1999, 3, 4, s. 278-302. 
łecznego, należy postrzegać dwuaspektowo ${ }^{15}$. Otóż, aktorzy społeczni są zwolnieni z konieczności interpretacji znaczeń w sytuacjach znanych, rozpoznawanych i oczekiwanych społecznie. Ważne są jednak dla nich spodziewane efekty w sytuacjach kiedy aktywnie w nich uczestniczą. Wówczas pozycjonują się $w$ określonych zestawach interakcyjnych, postrzegając swój status poprzez pryzmat wrażenia, jakie wywierają na innych i na sobie samych.

Z uwagi na ograniczoną objętość artykułu zarówno rozwinięcie fundamentu interakcyjnego, jak i omówienie innych teorii (systemów, gier, sieci, kapitału społecznego i zachowania zasobów), przyjętych w holistycznej, sieciowo-systemowej koncepcji (re)integracji społecznej, zostanie wkrótce zaprezentowane w publikacji zwartej.

Wracając do meritum zagadnienia, jądrem zarówno analiz teoretycznych, jak i układu modelowego uczyniłam ideę i teorię klasteringu, spójną z przyjętymi teoriami socjologicznymi, ale lokującą się w obszarze nowoczesnego zarządzania i organizacji.

\section{Klastering jako szczególna forma (re)integracji społecznej}

Zastosowanie idei i teorii klasteringu w projektowaniu działań readaptacyjno-reintegracyjnych wiąże się z koniecznością zmiany dotychczasowego sposobu myślenia, świadomej rezygnacji z dotychczasowego, tunelowego modelu działania społecznego oraz przyjęcia podejścia holistycznego, sieciowo-systemowego. U jego podstaw leży budowanie - głównie na poziomie wsparcia lokalnego - sieci stałej współpracy międzyinstytucjonalnej (sformalizowanej i długotrwałej), wzmacnianej obywatelską działalnością akcyjną (spontaniczną i krótkotrwałą) ${ }^{16}$. Istotą strategii sieciowo-systemowej jest równoległe uruchamianie kooperacji pionowej (współpraca podejmowana przez instytucje społeczne tego samego typu, np. gminne ośrodki pomocy społecznej) i poziomej (współpraca różnorakich instytucji - formalnych, nieformalnych, ekonomicznych, religijnych, wychowawczych, kulturalnych

${ }^{15}$ A. Manterys, Sytuacje społeczne.

16 Koncepcja sieciowo-systemowego działania społecznego nawiązuje do klasycznej oraz współczesnej pedagogiki społecznej i resocjalizacyjnej - koncepcji „sił społecznych" autorstwa H. Radlińskiej, „spirali życzliwości” S. Kawuli, "małych ojczyzn” propagowanych przez W. Theissa, koncepcji „uspołecznionego systemu profilaktyki i resocjalizacji” W. Ambrozika, „wielopasmowej teorii resocjalizacji z udziałem społeczeństwa” A. Bałandynowicza oraz „twórczej resocjalizacji” M. Konopczyńskiego. 
i socjalnych, działających na rzecz tego samego beneficjenta, np. ekswięźniów i ich rodzin).

Struktura sieci kooperacyjnej zapewnia warunki do twórczego myślenia, daje poczucie więzi zespołowej oraz osłabia poczucie ryzyka. $W$ tego typu działaniu społecznym uaktywniane są zróżnicowane potencjały, w tym postawy i zdolności intelektualne zarówno poszczególnych jednostek, jak i organizacji, niezbędne dla optymalizowania rozwiązań o wielokierunkowym zastosowaniu.

Sieć międzyinstytucjonalnej współpracy środowiskowej (horyzontalnej i wertykalnej) daje możliwość pojawienia się nowych właściwości bądź dodatkowych korzyści, co znacznie podnosi skuteczność i efektywność działania poprzez pojawienie się określonych cech, a raczej całej gamy efektów: synergii, kuli śniegowej, stymulacji, zwiększonego poczucia bezpieczeństwa oraz spontaniczności.

Generalnie rzecz ujmując, sieciowo-systemowe kreowanie działań społecznych umożliwia organizowanie pomocy i wsparcia readaptacyjnego o charakterze stabilizującym, terapeutycznym oraz resocjalizująco-destygmatyzującym i profilaktycznym zarazem. Jednoczesne, adekwatne do potrzeb i wielozakresowo prowadzone oddziaływania znacznie zwiększają szanse na wypracowanie u osób skazanych i ich rodzin zdolności do eksdewiacyjnej autokreacji, zwieńczonej pozytywną i trwałą reintegracją społeczną ${ }^{17}$.

W polskiej rzeczywistości brakuje zarówno rozwiązań prawnych, jak i systemowych skutecznie wspierających rodziny z problemem przestępczości, które w większości przypadków stanowią patogenne środowisko życia. Nie są one dostatecznie objęte działaniami mającymi na celu stabilizację ich głęboko dysfunkcyjnych systemów. Praca w tym zakresie wymaga prowadzenia oddziaływań resocjalizująco-readaptacyjnych, ukierunkowanych na uzupełnianie deficytów oraz zaspokajanie potrzeb indywidualnych i grupowych, a także kształtowanie, rozwijanie i/lub podtrzymywanie cech strukturalnych i dyspozycji funkcjonalnych systemu rodzinnego oraz cech osobowych, kompetencji społecznych i umiejętności personalnych członków rodziny. Konsekwencją zaniedbań w tym obszarze pomocowym jest najczęściej powrót skazanych do przestępstwa. Należy przy tym podkreślić, że problem przestępczości może dotknąć wprawdzie każdą rodzinę, ale najczęściej dotyczy tych rodzin, w których spirala kryzysu nakręca się wokół jego pierwotnego źródła: bezrobocia, biedy, czy uzależnień. Co więcej, rodziny te

${ }^{17}$ Zob.: B.M. Nowak, Kreowanie dziatań społecznych o charakterze resocjalizacyjno-readaptacyjnym. Podejście sieciowo-systemowe, Resocjalizacja Polska, 2014, 7. 
stanowią często źródło zapóźnień socjokulturowych. Z uwagi na negatywną percepcję otoczenia społecznego są one stygmatyzowane środowiskowo i lokowane w dyskredytowalnej kategorii - grupie rodzin upośledzonych społecznie ${ }^{18}$.

Wydaje się, że przyjęcie omawianego podejścia i opartego na nim modelu działania podniosłoby znacznie efektywność pomocy i wsparcia organizowanego na rzecz osób skazanych i ich rodzin. Sieci społeczne są bowiem wspólnie użytkowanym kapitałem (dobrem publicznym) i stanowią cenne zasoby ludzkie. W ich ramach ma miejsce wpływ społeczny, który jest najważniejszym czynnikiem zmiany postaw, gdyż umożliwia krystalizację norm w grupach społecznych oraz formowanie się opinii publicznej (również - kształtowanie tej opinii).

Zagadnienie związku między strukturą sieci społecznych a współpracą podmiotów w nich ulokowanych jest przedmiotem wielu analiz teoretycznych i empirycznych. Interesujące badania w tym zakresie przeprowadzili między innymi D.J. Watts i S.H. Strogatz oraz B. Uzzi i J. Sapiro ${ }^{19}$. Wyniki ich badań dowiodły, że największy sukces odnoszą sieci najsilniej przejawiające cechy charakterystyczne dla „małego świata”, w których uczestnicy wykazują się kreatywnością i elastycznością myślenia oraz wspólnym poszukiwaniem nowych, innowacyjnych rozwiązań. Moc sieci tkwi bowiem we wzajemnym wpływie, jaki w sprzężeniu zwrotnym wywierają na siebie uczestnicy sieciowej gry społecznej oraz w skłonności człowieka do naśladowania innych, co z kolei jest efektem normatywnego wpływu społecznego. Uczestnictwo w sieci, przejawiające się w podejmowaniu współpracy i współdziałania na rzecz osiągnięcia wspólnego celu, skutkuje pozyskaniem dużo większej zdolności oddziaływania na innych niż w przypadku indywidualnego działania.

W świetle powyższego, w przyjętą podstawę teoretyczną wpisuje się idea i teoria klasteringu, której twórca jest M. Porter, amerykański badacz struktur gospodarczych. Zaproponował on zmianę dotychczas obowiązującego paradygmatu, czyli przejście z bezwzględnej rywalizacji i konkurencji do rozbudowanej współpracy oraz kooperacji, jak również wprowadził nowy termin, który zdefiniował jako klaster, czyli

${ }^{18}$ Więcej na ten temat w: B.M. Nowak, Rodzina w kryzysie. Studium resocjalizacyjne, Warszawa 2011.

19 D.J. Watts, S.H. Strogatz, Collective dynamics of 'small-world' networks, Nature, International Weekly Journal of Science, 1998, 393, s. 440-442; B. Uzzi, J. Sapiro, Team Assembly Mechanisms Determine Collaboration Network Structure and Team Performance, http://www.kellogg. northwestern.edu/faculty/uzzi/ftp/guimera_et_al_science_2-2005_final.pdf [dostęp: 06.06. 2015]. 
(...) geograficzne skupisko wzajemnie powiązanych firm, wyspecjalizowanych dostawców, jednostek świadczących usługi, firm działających w pokrewnych sektorach i związanych z nimi instytucji (na przykład uniwersytetów, jednostek normalizacyjnych i stowarzyszeń branżowych) w poszczególnych dziedzinach, konkurujących między sobą, ale również współpracujących ${ }^{20}$.

Klastry wyodrębniane są na podstawie dwóch mechanizmów: buttom-up (inicjatywy oddolne) oraz top-down (inicjatywy odgórne). Klastry stanowią ośrodki wiedzy, innowacji technologicznych oraz źródła nowych standardów zarządzania ${ }^{21}$. Cechuje je oparcie działań na wiedzy, łączenie współpracy z konkurencją, geograficzne skupienie w jednym lub kilku sąsiadujących regionach; jednoczesna, a zarazem wspólna ścieżka rozwoju oraz silne i trwałe interakcje między uczestnikami sieci, które są twórcze oraz ukierunkowane na wypracowanie i konsekwentne realizowanie konkretnego programu współpracy.

Wraz z pojawieniem się efektu synergii w postaci dostępu do nowych informacji, nowych umiejętności, optymalizacji metod działania itp., klastry przekształcają się $\mathrm{w}$ system nie tylko o charakterze ekonomiczno-gospodarczym, ale także społecznym, wyzwalającym innowacyjność, pobudzającym kreatywność i nowatorstwo ${ }^{22}$. Powiększając sukcesywnie swoje potencjały, klastry stają się nośnikami wyspecjalizowanych zasobów (wiedzy i informacji, kadr, instytucji, zaplecza rozwojowego). Kluczowym ogniwem systemów klastrowych jest animator - instytucja mająca za zadanie diagnozowanie potencjalnych obszarów współpracy, potrzeb i oczekiwań, gotowości do kooperacji podmiotów deklarujących przystąpienie do klastra oraz koordynowanie działań ukierunkowanych na osiągnięcie wspólnego celu, przyjętego przez wszystkich uczestników klastra.

Dla opisanej wyżej struktury charakterystyczna jest koopetycja, stanowiąca nowoczesną formę integracji społecznej, która łączy dwa przeciwstawne, ale równocześnie występujące działania: współpracę i konkurencję. Ta swoista fuzja pozwala na pojawienie się nowej perspektywy23. Współcześni ekonomiści (m.in. J. Moor, A. Lozano, K. Walley) są bowiem przekonani,

${ }^{20}$ M. Porter, Porter o konkurencji, Warszawa 2001, s. 246.

${ }^{21}$ Zasady tworzenia klastrów w Polsce oraz procedury udzielania wsparcia finansowego na ich rozwój opisuje $\S 13$ ust. 2 Rozporządzenia ministra gospodarki w sprawie udzielania przez Polską Agencję Rozwoju Przedsiębiorczości pomocy finansowej niezwiązanej z programami operacyjnymi (DzU z 2006 r. nr 226, poz. 1651 z późn. zm.).

22 Potwierdzają to badania empiryczne: L. Palmen, M. Baron, Przewodnik dla animatorów inicjatyw klastrowych w Polsce, Warszawa 2008.

${ }_{23}$ G. Padula, G.B. Dagnino, Untangling the rise of coopetition: the intrusion of competition in a cooperative game structure, International Studies of Management \& Organization, 2007, 37(2), s. 32-52. 
że podejście koopetycyjne stwarza nowe pole eksploracji zarówno dla postępu badań, jak i praktyki w zakresie zarządzania strategicznego. Wprawdzie podejście to jest $\mathrm{w}$ fazie krystalizacji i wymaga opracowania odrębnego podejścia teoretycznego, ale już teraz dostrzegają oni jego wielką moc sprawczą.

Koopetycja jest rozumiana najczęściej jako „system aktorów działających na podstawie częściowej zgodności interesów i celów"24, ale de facto termin ten nie jest jeszcze dookreślony - jest neologizmem. Z jednej strony bowiem koopetycja postrzegana jest jako swoista efemeryda - zjawisko hybrydowe lub fenomen gospodarczy, z drugiej natomiast - bardziej pragmatycznie jako współzależność 25 , strategia, czy forma dynamiki międzyorganizacyjnej. Większość prób zdefiniowania tego terminu uwzględnia jednak podstawowy rys, a jest nim zespalanie się konkurencji i kooperacji $\mathrm{w}$ jeden typ relacji i interakcji, w myśl neoplatońskiej coincidentia oppositorum, czyli zbieżności przeciwieństw. W ujęciu G.B. Dagnino, orientacja koopetycyjna jest ukierunkowaniem na współdziałanie ${ }^{26} \mathrm{w}$ ramach podejmowanych relacji poziomych i pionowych ${ }^{27}$. Z kolei Bengtson, Hinttu i Kock, nawiązując do teorii zasobów oraz teorii sieci, stoją na stanowisku, że koopetycja to jeden z typów relacji międzyorganizacyjnych ${ }^{28}$.

Istotę koopetycji ukazuje jednak najpełniej teoria gier. Tradycyjnie postrzegana gra rynkowa bazująca na dwupodmiotowych interakcjach typu wygrany - przegrany (win - lose), w połowie lat 90. XX wieku ewoluowała do sytuacji wygrany - wygrany (win - win). Jednak gra toczy się dalej, bowiem okazało się, że można wygenerować wielostronną sytuację typu: wygrany - wygrany - wygrany (win - win) ${ }^{29}$. I właśnie w tym działaniu G.B. Dagnino lokuje istotę oraz wartość koopetycji. Aktorzy społeczni (instytucje, przedsiębiorstwa, organizacje, instytuty naukowe) wchodząc elastycznie i często naprzemiennie $\mathrm{w}$ role usługodawców, partnerów, klientów, czy konkurentów, realizują strategię wspólnego tworzenia wartości i ewoluują

24 G.B. Dagnino i in., Strategie koopetycji - nowa forma dynamiki międzyorganizacyjnej? Przegląd Organizacji, 2008, 16.

${ }_{25}$ G.B. Dagnino, Coopetition Strategy. A New Kind of Interfirm Dynamics for Value Creation, [w:] Coopetition Strategy. Theory, Experiments and Cases, red. G.B. Dagnino, E. Rocco, London New York 2009.

${ }^{26}$ Tamże.

27 A.M. Brandenburger, B.J. Nalebuff, Coopetition, Doubleday, New York 1996.

28 M. Bengtson, S. Hinttu, S. Kock, Relationships of Cooperation and Competition Between Competitors, Work-in-Progress Paper submitted to the 19 th Annual IMP Conference, September 2003 (4-6), Lugano Switzerland [online] http://www.impgroup.org/uploads/papers/ 4294.pdf [dostęp: 03.05.2015].

${ }^{29}$ K. Walley, Coopetition. An Introduction to the Subject and Agenda for Research, International Studies of Management \& Organization, 2007, 37, 2, s. 16. 
równocześnie w zakresie tej samej wizji - zawierania sojuszy, negocjacji, czy nawiązywania relacji $\mathrm{w}$ obszarze zarządzania i administrowania ${ }^{30}$. Powoduje to, że wszystkie podmioty interakcji lokowane są na pozycji wygranej. Co więcej, korzyści płynące ze zmiany postępowania poprzez przyjmowanie różnych ról w systemie klastrowym mogą być znacznie większe niż uzyskiwane w trakcie utrzymywania status quo ${ }^{31}$.

Oprócz perspektywy wynikającej z teorii gier, z przeglądu różnych podejść badawczych w wyjaśnianiu zjawiska koopetycji, użyteczne dla niniejszych rozważań uznałam także perspektywy:

- klastra - koopetycja jako źródło dostępu do unikatowych zasobów i nośnik kreatywności organizacyjnej (Jankowska 2012) ${ }^{32}$;

- zasobowa - koopetycja jako wartość powstała w wyniku połączenia wiedzy z innymi graczami (Levy, Loebbecke, Powell, 2003) ${ }^{33}$ - źródłem przewagi konkurencyjnej mogą być unikalne zasoby (materialne i niematerialne), zwłaszcza w postaci zdolności i kompetencji, a podmioty działające zgodnie z zasadami koopetycji współewoluują zarówno w zakresie konkurencji, jak i współpracy;

- sieci - koopetycja w układach sieciowych jest nośnikiem zarówno autonomii, jak i zależności (Stańczyk-Hugiet 2012) ) $^{34}$.

Liczne korzyści osiągane ze stosowania strategii koopetycji, które stanowią podstawowe motywy do podejmowania działań o tym charakterze, odnoszą się przede wszystkim do 35 :

- wzajemnego uczenia się i pobudzania innowacyjności,

- doskonalenia i tworzenia nowych rozwiązań technologicznych,

- obniżania kosztów prac badawczo-rozwojowych,

- obniżenia kosztów transakcyjnych,

- osiągnięcia synergii,

${ }^{30}$ B. Jankowska, Koopetycja $w$ klastrach kreatywnych. Przyczynek do teorii regulacji w gospodarce rynkowej, Poznań 2013, s. 5.

${ }^{31}$ A.M. Brandenburger, B.J. Nalebuff, Coopetition.

32 B. Jankowska, Koopetycja w klastrach kreatywnych.

${ }_{33} \mathrm{M}$. Levy, C. Loebbecke, P. Powell, SMEs, coopetition, and knowledge sharing: the role of information systems, European Journal of Information Systems, 2003, 12, 1.

${ }^{34}$ E. Stańczyk-Hugiet, Autonomia i zależność w układach koopetycyjnych, Łódź 2012.

35 D.R. Gnyawali, R. Park, Coopetition and technological innovation in small and medium-sized enterprises: a multilevel conceptual model, Journal of Small Business Management, 2009, 47, 3; B. Bigliardi, A.I. Dormio, F. Galati, Successful coopetition strategy: evidence from an Italian consortium, International Journal of Business, Management and Social Sciences, 2011, 2, 4; A. Nemeh, S. Yami, Coopetition strategies and innovation in precompetitive RED programs: the case of wireless telecommunication sector, Druid, CBS, Copenhagen 2012, Denmark, http://druid8.sit.aau.dk/ acc_papers/v9e018pfuphhurs9khda84edn30i.pdf [dostęp: 6.06.2015]; B. Jankowska, Koopetycja w klastrach kreatywnych; E. Stańczyk-Hugiet, Autonomia i zależność. 
- wzrostu wartości firmy,

- dostępu do zasobów,

- wzmocnienia pozycji firmy wobec konkurentów nieobjętych układem koopetycyjnym,

- rozszerzenia skali działania.

Badania empiryczne wskazują na pozytywne skutki relacji kooperowania i konkurowania, jednak po pewnymi warunkami. Otóż, warunkiem koniecznym jest profesjonalne przygotowanie strategii koopetycji. Równie ważne jest przestrzeganie przez partnerów zasad kluczowych dla odniesienia sukcesu: poszanowania autonomii partnerów, uczciwości konkurencyjnej i koncentracji na współpracy w dążeniu realizacji wspólnie założonych celów. Pierwsze badania nad fenomenem koopetycji zostały przeprowadzone w 1996 roku przez A.M. Brandenburgera i B.J. Nalebuffa ${ }^{36}$. Na podstawie teorii gier próbowali wyjaśnić strategiczne współdziałanie między koopetytorami. Obecnie strategia koopetycji jest przedmiotem coraz większego zainteresowania naukowców, zwłaszcza badaczy francuskich, włoskich, szwedzkich i fińskich ${ }^{37}$, którzy analizują i opisują to zjawisko na różnych poziomach $^{38}$ :

- mikro (jednostki organizacyjne w jednym podmiocie);

- mezo (np. podmioty w klastrach);

- makro (np. klastry);

- globalnym (np. gospodarki narodowe).

$\mathrm{Na}$ wszystkich poziomach koopetytorzy mogą nawiązywać relacje o charakterze pionowym (wchodzą wówczas w role dostawców, klientów, usługodawców), poziomym (stają się bezpośrednimi konkurentami) oraz sieciowym (są uwikłani w splot relacji pionowych i poziomych) ${ }^{39}$. Będące istotą koopetycji dwa paralelne procesy - współpraca i konkurencja - są

36 A.M. Brandenburger, B.J. Nalebuff, Co-Opetition: A Revolution Mindset That Combines Competition and Cooperation: The Game Theory Strategy That's Changing the Game of Business, London 1996.

${ }^{37}$ M. Rogalski, Strategia koopetycji - światowe trendy eksploracji, Przegląd Organizacji, 2011, 9; tegoż, Geograficzne aspekty badań nad koopetycja - dominujące ośrodki badawcze w ujęciu regionalnym, Zarządzanie i Finanse, 2012, 1/2.

38 G.B. Dagnino, G. Padula, Coopetition strategy. A new kind of interfirm dynamics for value creation, EURAM - The European Academy of Management Second Annual Conference Innovative Research in Management", Stockholm, 9-11 May 200 [oneline]

http://www.researchgate.net/profile/Giovanni_Battista_Dagnino/publication/22860529 6_Coopetition_strategy_a_new_kind_of_interfirm_dynamics_for_value_creation/links/0912f5 11dacf4440c1000000.pdf [dostęp: 04.04.2015]; B. Jankowska, Koopetycja w klastrach kreatywnych, s. 59.

${ }^{39} \mathrm{H}$. Kotzab, Ch. Teller, Value-adding partnerships and co-opetition models in the grocery industry, International Journal of Physical Distribution and Logistics Management, 2003, 33, 3. 
jednak przeciwstawne i mogą generować napięcia międzyorganizacyjne. Dlatego, konieczne jest wypracowanie takiego strategicznego balansu, aby oczekiwane korzyści przeważały nad ewentualnymi zagrożeniami, którymi mogą być między innymi: niska efektywność realizowanych celów i procesów, zachowania oportunistyczne koopetytorów, konflikty paraliżujące współpracę, znaczna utrata niezależności decyzyjnej i organizacyjnej.

Biorąc pod uwagę powyższe rozważania, należy skonstatować, że idea $\mathrm{i}$ teoria klasteringu oraz strategia koopetycji mogą być wykorzystane $\mathrm{w}$ tworzeniu lokalnych sieci pomocy postpenitencjarnej, organizowanych $\mathrm{w}$ środowisku życia skazanych. Jednym z przykładów jednostki animującej i koordynującej działania podmiotów wchodzących w skład klastra reintegracyjnego mogłyby być Powiatowe Biura Wsparcia Readaptacyjnego (PBWR). W strukturze systemowej byłyby one podległe Readaptacyjnym Radom Terenowym zlokalizowanym w miastach wojewódzkich, kontrolowanym i nadzorowanym z kolei przez Radę Główną do spraw Społecznej Readaptacji i Pomocy Skazanym.

Główne działanie PBWR-ów, oparte na ścisłej współpracy z jednostkami samorządu terytorialnego oraz organizacjami pożytku publicznego, byłoby ukierunkowane na diagnozowanie potencjalnych obszarów współpracy, potrzeb i oczekiwań, jak też gotowości do kooperacji kolejnych podmiotów deklarujących przystąpienie do klastra. Kluczowym zadaniem Powiatowego Biura Wsparcia Readaptacyjnego byłoby stworzenie dwu baz informacyjnych:

- bazy danych pozyskiwanych z zakładów karnych odnośnie potrzeb skazanych powracających do miejsc stałego zamieszkania lub osiedlających się na terenie danego powiatu - w obu przypadkach niezbędne byłoby uruchomienie elektronicznego pomostu informacyjnego z zakładami karnymi, urzędami gmin i komisariatami policji;

- bazy danych o możliwościach otrzymania przez skazanych i ich rodziny realnego, lokalnego wsparcia readaptacyjnego.

Działalność koordynacyjna PBWR-ów obejmowałaby współpracę międzyinstytucjonalną w trzech strategicznych obszarach: edukacji - z Centrami Kształcenia Zawodowego i Ustawicznego oraz uczelniami funkcjonującymi na danym terenie; zatrudnienia - z Powiatowymi Urzędami Pracy (wydzielona pula ofert pracy dla byłych więźniów oraz kwalifikacyjnych kursów zawodowych); pomocy socjalnej - współpraca z instytucjami pomocy społecznej. Skazani i ich rodziny otrzymywaliby w ten sposób skonsolidowaną, celową i niedublowaną pomoc w zakresie zabezpieczenia socjalnego, reedukacji i edukacji zawodowej oraz silne wsparcie organizacji pożytku publicznego w zakresie rozwoju potencjałów i włączania ich w życie społeczności 
lokalnych. Należy w tym miejscu podkreślić, że projektowane, a następnie implementowane działania powinny uwzględniać predyspozycje osobowopoznawcze oraz możliwości rozwojowe skazanych i członków ich rodzin.

\section{Podsumowanie}

Niesprawność współczesnego systemu pomocy postpenitencjarnej niejako wymusza konieczność zmiany dotychczasowego modelu organizacji pomocy i wsparcia na rzecz skazanych i ich rodzin. Podejście, które wychodzi naprzeciw temu wyzwaniu, leży u podstaw sieciowo-systemowej koncepcji (re)integracji społecznej. Opracowanie efektywnego modelu działań społecznych na rzecz osób skazanych i ich rodzin, a także innych podmiotów - zmarginalizowanych, zagrożonych wykluczeniem i wykluczonych społecznie - wymaga jednak przyjęcia szerokiej perspektywy interdyscyplinarnej, kreatywnej adaptacji idei i teorii klasteringu (nie ich kopiowania) oraz oparcia modelu na wynikach badań empirycznych nad osobowościowymi, a zwłaszcza środowiskowymi przyczynami powrotności do przestępstwa.

Należy podkreślić, że prace nad prezentowanymi w artykule zagadnieniami wciąż trwają, a wiele istotnych pytań nadal pozostaje bez odpowiedzi. Jestem jednak głęboko przekonana, że jedynie poszukiwania $\mathrm{w}$ dorobku innych dziedzin nauki dają szansę na dokonanie przełomu w sztampowym myśleniu o organizacji pomocy i wsparcia readaptacyjno-reintegracyjnego. Ujęcie interdyscyplinarne może dostarczyć kluczowych danych i wygenerować skuteczne rozwiązania, ale może też inspirować i pobudzać kreatywność badaczy tego bardzo trudnego obszaru działania społecznego.

\section{BIBLIOGRAFIA}

Bigliardi B., Dormio A.I., Galati F., Successful coopetition strategy: evidence from an Italian consortium, International Journal of Business, Management and Social Sciences, 2011, 2,4 .

Blau P.M., Structures of social positions and structures of social relations, [w:] Theory building in sociology: assessing theoretical cumulations, red. J.H. Turner, Sage Publications, Newbury Park, CA 1989.

Blumer H., Interakcjonizm symboliczny: perspektywa i metoda, przekł. G. Woroniecka, red. nauk. A. Manterys, Zakład Wydawniczy Nomos, Kraków 2007.

Brandenburger A.M., Nalebuff B.J., Coopetition, Doubleday, New York 1996. 
Brandenburger A.M., Nalebuff B.J., Coopetition: A Revolution Mindset That Combines Competition and Cooperation: The Game Theory Strategy That's Changing the Game of Business, Harper-Collins-Business, London 1996.

Dagnino G.B., Coopetition Strategy. A New Kind of Interfirm Dynamics for Value Creation, [w:] Coopetition Strategy. Theory, Experiments and Cases, red. G.B. Dagnino, E. Rocco, Routledge Taylor \& Francis Group, London - New York 2009.

Dagnino G.B., Le Roy F., Yami S., Czakon W., Strategie koopetycji - nowa forma dynamiki międzyorganizacyjnej? Przegląd Organizacji, 2008, 16.

Gnyawali D.R., Park R., Coopetition and technological innovation in small and medium-sized enterprises: a multilevel conceptual model, Journal of Small Business Management, 2009, 47,3 .

Goffman E., Piętno. Rozważania o zranionej tożsamości, Gdańskie Wydawnictwo Pedagogiczne, Gdańsk 2007.

Goffman E., Człowiek w teatrze życia codziennego, Państwowy Instytut Wydawniczy, Warszawa 2009.

Hall P.M., Hewitt J.P., The quasi-theory of communication and the management of dissent, Social Problems, 1970, 18, 1.

Jankowska B., Koopetycja w klastrach kreatywnych. Przyczynek do teorii regulacji w gospodarce rynkowej, Wydawnictwo UE w Poznaniu, Poznań 2013.

Kotzab H., Teller Ch., Value-adding partnerships and co-opetition models in the grocery industry, International Journal of Physical Distribution and Logistics Management, 2003, 33,3 .

Levy M., Loebbecke C., Powell P., SMEs, coopetition, and knowledge sharing: the role of information systems, European Journal of Information Systems, 2003, 12, 1.

Liszke W., Przygotowanie skazanego do życia po zwolnieniu z zakładu karnego przez kuratora sacowego, Probacja, 2009.

Lofland J., Doing social life: a qualitative study of human interaction in natural settings, Willey, New York 1976.

Manterys A., Sytuacje społeczne, Zakład Wydawniczy Nomos, Kraków 2008.

Najwyższa Izba Kontroli, Wdrożenie i eksploatacja systemu dozoru elektronicznego oraz realizacja zadań przez sąowych kuratorów zawodowych w procesie wykonywania kary pozbawienia wolności w tym systemie, Wydawnictwo Departamentu Porządku i Bezpieczeństwa Publicznego, Warszawa, lipiec 2014.

Najwyższa Izba Kontroli, Readaptacja społeczna skazanych na wieloletnie kary pozbawienia wolności, Wydawnictwo Departamentu Porządku i Bezpieczeństwa Publicznego, Warszawa, listopad 2015.

Nowak B.M., Rodzina w kryzysie. Studium resocjalizacyjne, Wydawnictwo Naukowe PWN, Warszawa 2011.

Nowak B.M., Skuteczność oddziaływań resocjalizacyjnych w percepcji kuratorów sądowych, [w:] Tożsamość osobowa dewiantów a ich reintegracja społeczna, red. A. Kieszkowska, Oficyna Wydawnicza Impuls, Kraków 2011.

Nowak B.M., Kreowanie działań społecznych o charakterze resocjalizacyjno-readaptacyjnym. Podejście sieciowo-systemowe, Resocjalizacja Polska, 2014, 7.

Padula G., Dagnino G.B., Untangling the rise of coopetition: the intrusion of competition in a cooperative game structure, International Studies of Management \& Organization, 2007, 37(2).

Palmen L., Baron M., Przewodnik dla animatorów inicjatyw klastrowych w Polsce, PARP, Warszawa 2008. 
Porter M., Porter o konkurencji, Państwowe Wydawnictwo Ekonomiczne, Warszawa 2001. Rogalski M., Strategia koopetycji - światowe trendy eksploracji, Przegląd Organizacji, 2011, 9.

Rogalski M., Geograficzne aspekty badań nad koopetycja - dominujące ośrodki badawcze w ujęciu regionalnym, Zarządzanie i Finanse, 2012, 1/2.

Rymsza M. (red.), Czy podejście aktywizujace ma szansę? Pracownicy socjalni i praca socjalna w Polsce 20 lat po reformie systemu pomocy spotecznej, Wydawnictwo Instytutu Spraw Publicznych, Warszawa 2011.

Rymsza M., Pracownicy socjalni i praca socjalna w Polsce. Między stużba społeczna a urzędem, Wydawnictwo Instytutu Spraw Publicznych, Warszawa 2012.

Stańczyk-Hugiet E., Autonomia i zależność w układach koopetycyjnych, Studia Ekonomiczne Regionu Łódzkiego, PTE Oddział w Łodzi, Łódź 2012.

Watts D.J., Strogatz S.H., Collective dynamics of 'small-world' networks, "Nature", International Weekly Journal of Science, 1998, 393.

Thompson L., Fine G.A., Socially shared cognition, affect and behavior: a review and integration, Personality and Social Psychology Review, 1999, 3, 4.

Walley K., Coopetition. An Introduction to the Subject and Agenda for Research, International Studies of Management \& Organization, 2007, 37, 2.

\section{Netografia}

Bengtson M., Hinttu S., Kock S., Relationships of Cooperation and Competition Between Competitors, Work-in-Progress Paper submitted to the 19 th Annual IMP Conference, September 2003 (4-6), Lugano Switzerland [online]

http://www.impgroup.org/uploads/papers/4294.pdf [dostęp: 03.05.2015].

Dagnino G.B., Padula G., Coopetition strategy. A new kind of interfirm dynamics for value creation, EURAM - The European Academy of Management Second Annual Conference - „Innovative Research in Management”, Stockholm, 9-11 May 2002 [online]

http://www.researchgate.net/profile/GiovanniBattistaDagnino/publication/228605296 _Coopetition_strategy_a_new_kind_of_interfirm_dynamics_for_value_creation/link s/0912f511dacf4440c1000000.pdf [dostęp: 04.04.2015].

Nemeh A., Yami S., Coopetition strategies and innovation in precompetitive RED programs: the case of wireless telecommunication sector, Druid, CBS, Copenhagen, Denmark 2012 [online]

http://druid8.sit.aau.dk/acc_papers/v9e018pfuphhurs9khda84edn30i.pdf [dostęp: 06.06. 2015].

Uzzi B., Sapiro J., Team Assembly Mechanisms Determine Collaboration Network Structure and Team Performance [online]

http://www.kellogg.northwestern.edu/faculty/uzzi/ftp/guimera_et_al_science_22005_final.pdf [dostęp: 06.06.2015]. 